\title{
ATP and Its Metabolite Adenosine as Regulators of Dendritic Cell Activity
}

\author{
Cinthia Silva-Vilches, Sabine Ring and Karsten Mahnke* \\ Department of Dermatology, Ruprecht-Karls-University Heidelberg, University Hospital, Heidelberg, Germany
}

Adenosine (Ado) is a well-studied neurotransmitter, but it also exerts profound immune regulatory functions. Ado can (i) actively be released by various cells into the tissue environment and can (ii) be produced through the degradation of extracellular ATP by the concerted action of CD39 and CD73. In this sequence of events, the ectoenzyme CD39 degrades ATP into ADP and AMP, respectively, and CD73 catalyzes the last step leading to the production of Ado. Extracellular ATP acts as a "danger" signal and stimulates immune responses, i.e. by inflammasome activation. Its degradation product Ado on the other hand acts rather anti-inflammatory, as it down regulates functions of dendritic cells (DCs) and dampens T cell activation and cytokine secretion. Thus, the balance of proinflammatory ATP and anti-inflammatory Ado that is regulated by $\mathrm{CD} 39^{+} / \mathrm{CD} 73^{+}$ immune cells, is important for decision making on whether tolerance or immunity ensues. DCs express both ectoenzymes, enabling them to produce Ado from extracellular ATP

OPEN ACCESS

Edited by:

Christian Muenz,

Universität Zürich, Switzerland

Reviewed by:

Sven Burgdorf;

Universität Bonn, Germany Amanda S. MacLeod,

Duke University, United States

${ }^{*}$ Correspondence:

Karsten Mahnke

karsten.mahnke

@med.uni-heidelberg.de

Specialty section:

This article was submitted to Antigen Presenting Cell Biology, a section of the journal Frontiers in Immunology

Received: 31 July 2018 Accepted: 19 October 2018 Published: 09 November 2018

Citation:

Silva-Vilches $C$, Ring S and Mahnke $K$ (2018) ATP and lts Metabolite Adenosine as Regulators of Dendritic Cell Activity. Front. Immunol. 9:2581. doi: 10.3389/fimmu.2018.02581 by activity of CD73 and CD39 and thus allow dampening of the proinflammatory activity of adjacent leukocytes in the tissue. On the other hand, as most DCs express at least one out of four so far known Ado receptors (AdoR), DC derived Ado can also act back onto the DCs in an autocrine manner. This leads to suppression of DC functions that are normally involved in stimulating immune responses. Moreover, ATP and Ado production thereof acts as "find me" signal that guides cellular interactions of leukocytes during immune responses. In this review we will state the means by which Ado producing DCs are able to suppress immune responses and how extracellular Ado conditions DCs for their tolerizing properties.

Keywords: dendritic cells, adenosine, CD73, tolerance, ATP

\section{ADENOSINE TRIPHOSPHATE (ATP) IN PERIPHERAL TISSUES}

The chemical family of purines comprises of heterocyclic aromatic organic compounds, consisting of a pyrimidine ring fused to an imidazole ring. It comprehends biologically active molecules such as Adenosine-triphosphate (ATP) and its degradation product adenosine (Ado). ATP is widely known as an energy carrier within cells, but it can also be released from cells into the environment by cell membrane channels (gap junctions, pannexin channels) or specialized transporters (Figure 1) (1-4). Once located in the intercellular space, ATP transmits signals to other cells by engaging $\mathrm{P} 2$ receptors. $\mathrm{P} 2$ receptors can be divided into $\mathrm{P} 2 \mathrm{X}$ and $\mathrm{P} 2 \mathrm{Y}$ subtypes, which comprise different members as indicated by numbers, e.g., $\mathrm{P} 2 \mathrm{X}_{1}$ to $\mathrm{P} 2 \mathrm{X}_{7}$ and $\mathrm{P} 2 \mathrm{Y}_{1}, \mathrm{P}_{2} \mathrm{Y}_{2}, \mathrm{P} 2 \mathrm{Y}_{11}$. While all $\mathrm{P} 2 \mathrm{X}$ receptors bind ATP, only the $\mathrm{P}_{2} \mathrm{Y}_{1}, \mathrm{P}_{2} \mathrm{Y}_{2}$, and $\mathrm{P} 2 \mathrm{Y}_{11}$ receptors are engaged by ATP. The mode of action of $\mathrm{P} 2 \mathrm{X}$ and $\mathrm{P} 2 \mathrm{Y}$ receptors differs also and can be described as ionotropic for $\mathrm{P} 2 \mathrm{X}$ receptors, or metabotropic G-protein coupled in case of $\mathrm{P} 2 \mathrm{Y}$ types. The $\mathrm{P} 2 \mathrm{X}_{7}$ receptor is a 
well-studied example and serves as prototypic ATP receptor in many investigations. P2X receptors often form multimeric complexes that upon engagement open a pore for cations such as $\mathrm{Na}^{+}, \mathrm{Ca}^{2+}$, or $\mathrm{K}^{+}$(5). This ion flux will then induce further intracellular signaling events. The most important pathway triggered by P2X receptors involves activation of the NLRP3 inflammasome, leading to caspase-1 activation, which in turn activates interleukin (IL-) $1 \beta$ and IL-18, two important pro inflammatory cytokines. But this is only one well studied example. In particular the transmembrane flux of $\mathrm{Ca}^{2+}$ ions can trigger multiple signaling events in cells involving mitogen activated kinases (MAPK), protein kinase C (PKC) and calmodulin. Therefore, many more effects of ATP induced signaling in leukocytes have been described These comprise the activation of T cells, (6-8), the release of IL-6, TNF (9, 10), prostaglandin (11), CXCL8, CCL2, CCL3 $(12,13)$ and metalloproteinase 9 (14), just to name a few [comprehensive list in Zimmermann. (15)]. The $\mathrm{P}_{2} \mathrm{Y}_{1}$ receptor, which is binds ATP in rodents and the $\mathrm{P}_{2} \mathrm{Y}_{2}$ receptor act via $\mathrm{Gq}$ coupled receptors and phospholipase C. Downstream, the second messengers inositol 1,4,5-triphosphate (IP3) that signals further via intracellular $\mathrm{Ca}^{2+}$ levels and diacylglycerol (DAC), which activates PKC, are produced. This rather general activation scheme illustrates the diverse groups of effects that can be induced by P2Y receptor engagement. Indeed, involvement of P2Y receptors in regulating hormone release and CNS activity has been documented in many instances. Beyond that, P2Y receptors are expressed by neutrophils, monocytes and $\mathrm{T}$ cells, indicating a role for immune regulation as well.

Due to the potent immune stimulatory actions of ATP, the extracellular concentrations are kept in check by enzymatic digestion of ATP. ATP is degraded fast within tissues, making it difficult to investigate its controlled release in defined organs in vivo. However, as skin is assessable for manipulation and measurement of ATP (16) and harbors several phenotypically distinct DC subtypes (17), it may be an organ of choice for investigating purine mediated signaling in vivo. At first, under non-inflammatory conditions the initial differentiation of skin keratinocytes (KCs) is guided by ATP. Upon binding of ATP the intracellular calcium levels rise gradually (as KCs express different subsets of ATP-specific P2X receptors depending on the layer), inducing the differentiation of the KCs $(18,19)$. Even the terminal differentiation and subsequent apoptosis of $\mathrm{KC}$ in the junction between stratum granulosum and stratum corneum seems to be dependent on ATP. Here, extensive colocalization of $\mathrm{P}_{2} \mathrm{X}_{7}$ receptors with caspase- 3 is evident (20), suggesting induction of cell death by ATP. This is corroborated by in vitro data, showing that prolonged engagement of $\mathrm{P} 2 \mathrm{X}_{7}$ receptors leads to extended pore-opening enabling even macromolecules of up to $900 \mathrm{Da}$ to travel into cells, leading to induction of

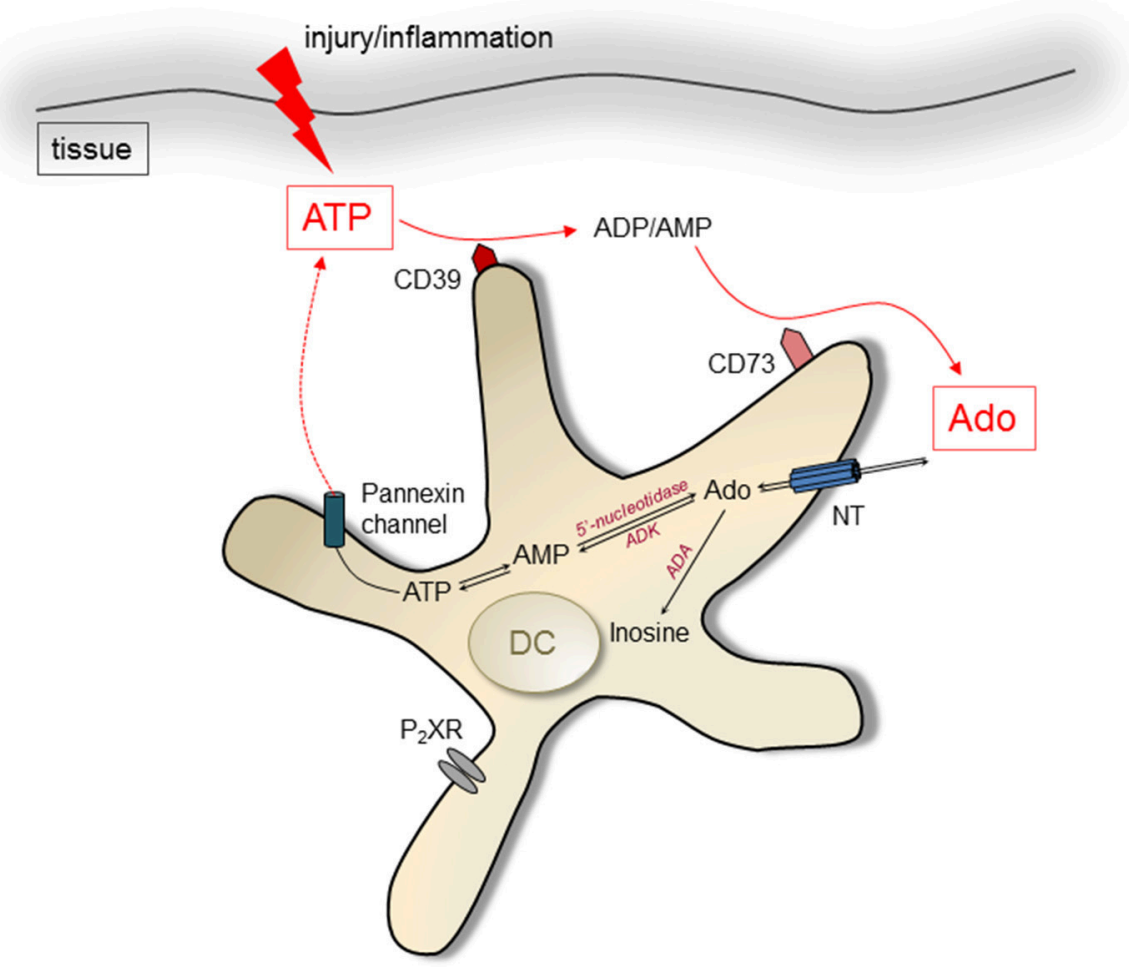

FIGURE 1 | Pathways of ATP/Ado generation in DCs. Intracellular Ado can be produced by degradation of AMP by $5^{\prime}$ ectonucleotidases. Nucleoside transporters (NT) lead to extrusion of Ado. ATP can be released by cells via pannexin channels after injury and during inflammation, acting immune stimulatory by engagement of P2X receptors (P2XR). It can be degraded by the ectoenzymes CD39 and CD73, resulting in increased levels of Ado in the extracellular environment. Ado can be degraded by action of the enzyme Adenosine deaminase (ADA) intra- and extracellularly. 
caspase-dependent cell death (21). Beyond serving as messenger involved in skin differentiation, ATP has also clear functions as a danger molecule. Due to its function as activator of the NLRP3 inflammasome, ATP is involved in triggering skin allograft rejection. Here it has been shown that ATP is released by host cells in response to transplantation leading to IL-18 production and Th1 responses. Moreover, the skin may "use" ATP even to alert the peripheral immune system, as monocytes during acute rejection of transplants exhibited higher expression of $\mathrm{P}_{2} \mathrm{X}_{7}$ receptors (22). Skin, as opposed to most other organs, is exposed to UV irradiation. This causes DNA damage, which produces a special set of danger signals. In response to UV irradiation, ATP is released by KCs triggering activation and release of IL17 by dendritic epidermal $\gamma \delta \mathrm{T}$ cells (23). Once activated, $\gamma \delta$ $\mathrm{T}$ cells can release ATP by themselves, leading to an autocrine activation loop maintained by $\mathrm{P}_{4} \mathrm{X}_{4}$ receptors (24). Functionally this sustained production of IL-17 is of importance for limiting adverse effects of UV, as it upregulates genes necessary for DNAdamage repair, such as TNF-related weak inducer of apoptosis (TWEAK) and the growth arrest gene GADD45 (23). Therefore, in case of UV induced cancers, therapeutic enhancement of extracellular ATP may offer a way for treatment.

Also in chronically diseased skin the distribution of ATP and its receptors change. For instance, in psoriatic plaques $\mathrm{P}_{2} \mathrm{X}_{7}$ receptors were found to be upregulated in the basal cell layer, suggesting that activation of KCs is facilitated by ATP (25). ATP is indeed elevated under pathological conditions, as it can be released by IFN $\gamma$ activated and/or dying leukocytes and KCs (26, 27). Moreover, early results demonstrated defective hydrolysis of ATP in the psoriatic epidermis, leading to accumulation of extracellular ATP in the diseased skin, which supports the notion that ATP is profoundly involved in development of psoriasis (28). These early studies were recently confirmed by Killeen et al. (29), showing in the dermis of psoriatic lesions in a skin explant model elevated expression of $\mathrm{P} 2 \mathrm{X}_{7}$ receptors as compared to healthy skin. This increased $\mathrm{P}_{2} \mathrm{X}_{7}$ signaling lead also to a phenotype of skin-DCs that predominantly induced Th17 cells, which are the main drivers of psoriasis. Finally, the elevated ATP concentrations in skin can also activate neutrophils, which in conjunction with IL-23, form a local inflammatory circuit maintaining psoriasiform dermatitis in mice (30). Therefore, increased levels of ATP together with enhanced expression of ATP receptors seem to be involved in maintaining an inflammatory environment in psoriatic skin.

On the other hand counter regulatory mechanisms directly related to the degradation product of ATP, i.e., Ado, have been described too. For instance, chronically stimulated epidermal KCs have an altered expression pattern of different Ado receptor (AdoR) types, with the rather pro-proliferative acting $\mathrm{A}_{2} \mathrm{~A}$ receptor upregulated and reduced expression of the inhibitory $\mathrm{A}_{2} \mathrm{~B}$ receptor (31). These and other observations led to investigations that utilize topical application of AdoR agonists for the treatment of psoriasis. Indeed, engagement of the AdoR $\mathrm{A}_{3}$ leads to reduced production of IL-17 and IL-23 in KCs of psoriatic patients, inducing amelioration of the disease $(32,33)$. Therefore, several drugs acting as agonist for different types of AdoR are currently used in clinical trials of skin- and other inflammatory diseases $(34,35)$. But not only in inflammatory diseases ATP plays a role, it is also important for induction of acute inflammation in skin. Weber et al. have shown that skin DCs without functioning $\mathrm{P}_{2} \mathrm{X}_{7}$ receptors are unable to sensitize $\mathrm{T}$ cell responses, indicating a role for directed ATP release as mediator of innate immune reactions (16). At the same time it became clear that haptens only act as trigger for hypersensitivity reactions when they induce release of ATP. Therefore, even experimental attempts were made to predict the "allergic potential" of chemicals by their ability to induce ATP release in KC cultures (36).

\section{ATP as Substrate for Adenosine Production}

A major degradation product of ATP is Ado, which can be generated intracellularly as well as extracellularly. Ado derives from the dephosphorylation of ATP, catalyzed by different enzymes: the ectonucleoside triphosphate diphosphohydrolase 1 (CD39) and the ecto-5'-nucleotidase (CD73) (37, 38). Both enzymes act sequentially in degrading extracellular ATP to adenosine. In a first step CD39 converts ATP to adenosinedi-phosphate and adenosine-mono-phosphate. In a second step the action of CD73 clips off the last remaining phosphate group, producing Ado (39). Ado can be released by nucleoside transporters from the cytoplasm of cells (4), however, the extracellular degradation of ATP by CD39 and CD73 is thought to provide the major pathway for regulating extracellular Ado concentrations. Its degradation is accomplished by adenosine deaminase (ADA), which exists in intra- as well as extracellular forms $(40,41)$. Extracellular ADA can bind to CD26 (42). Thus, similar to ATP and ADP, Ado can be degraded to inosine by cell membrane bound enzymes. In summary, the regulated destruction of extracellular ATP to Ado by enzymatic digestions offers cells a possibility to shape the tissue environment from a pro-inflammatory (high concentrations of free ATP) to a rather immunosuppressive (elevated levels of Ado) ambiance (43). As DCs express CD39 and/or CD73 as well as AdoR, they actively participate in immune responses affected by Ado (Figure 1).

\section{Regulation of Extracellular Ado and ATP Concentrations}

In light of the opposing functions of the two mutually transformable signaling molecules ATP (activating) and Ado (suppressing) on immune reactions, their temporal/spatial distribution in tissues or along the plasma membranes of cells is of importance. Cells will presumably integrate activating (ATP) and suppressive (Ado) signaling pathways rendering a "final" outcome. Therefore, the half live as well as the diffusion speed through tissues is a critical factor determining the effects of ATP/Ado signaling. Real "in tissue" data of the distribution of extracellular ATP or Ado, respectively, are hardly available. However, contents in body fluids or organ cultures can be measured. For instance, in dog as well as human plasma Ado is only stable for a few seconds (44), making it a "short range" molecule. This rapid degradation may be useful to prevent a generalized immune suppression and it further prevents Ado from reaching the central nervous system, where it acts as neurotransmitter (45) and elevated levels may therefore disturb 
nerve functions. Moreover, a short half-life makes Ado a more defined tool for cellular communication. Because only cells that harbor CD73 on their surfaces are able to produce sufficient amounts of Ado that then acts locally by engaging AdoR of adjacent cells. This mechanism may in particular of importance for tolerance induction, as Ado production by CD73 expressing DCs is required during the intimate DC:T cell priming process in order to render $\mathrm{T}$ cells tolerant (own unpublished results). Finally, to regulate Ado concentrations in relation to ATP not only the half-life is important, also the regulation of expression of the Ado producing ectoenzyme CD73 provides a means to fine tune the extracellular Ado content. During ischemic preconditioning expression of CD73 is induced within $30 \mathrm{~min}$ (46), greatly enhancing the extracellular Ado concentration in tissues and thereby overcoming the degradation by ADA.

For ATP biosensors are available (47) making is more feasible to monitor extracellular ATP content in cell culture settings. The reported half live of ATP varies from up 2-20 min depending on the organ and the methods used (48-51). Of note, in the immune system ATP actions are rather fast, as neutrophils show a burst of ATP release for only $5 \mathrm{~s}$ after being stimulated with fMLP (52). However, these data are once more obtained in in vitro culture systems, which differ from the in situ situation, but after all these data give an impression on the speed and range of ATP or Ado signaling. It provides evidence that Ado may not act "cytokinelike" with distribution via the blood stream and exerting action(s) in tissues far from its origin.

\section{EFFECTS OF Ado ON DCs}

\section{Expression of Ado Receptors by DCs}

Four Ado Receptors (AdoR) are known so far $\left(\mathrm{A}_{1}, \mathrm{~A}_{2} \mathrm{~A}, \mathrm{~A}_{2} \mathrm{~B}\right.$, and $\left.A_{3}\right)$. Structurally they all belong to G-protein-coupled-receptors (GPCRs), but their intracellular signaling differs (Figure 2). In general the $A_{2}$ receptor types are $G_{\alpha s}$-protein coupled receptors, with the $A_{2} B$ receptor additionally signaling via $G \alpha q$. In cells an activated $G$ protein complex forms at the inner leaflet of the cell membrane after Ado engagement, which leads to activation of the adenylate cyclase (AC) and to rising cAMP levels (in case of $G_{\alpha s}$ ). As a consequence protein kinase $A$ (PKA) is activated as secondary effector. On a molecular level this can directly be counteracted by engagement of $A_{1}$ or $A_{3}$ AdoR, which signal via $G_{\alpha i} / G_{\alpha q}$ complexes. Among them, the $\mathrm{G}_{\alpha \mathrm{i} / \mathrm{o}}$ complex inhibits $\mathrm{AC}$ activity and thus dampens $\mathrm{A}_{2}$ mediated signaling. The main signal transduction of $\mathrm{A} 1$ and $A 3$ receptors downstream of $G$ proteins is mediated by phospholipase $\mathrm{C}$ induced secondary messengers that ultimately leads to increased $\mathrm{Ca}^{2+}$ levels and PKC activation. Thus, a different secondary effector is induced by $A_{1}$ and $A_{3}$ AdoR, resulting in activation of different sets of genes. But nevertheless, even here a crosstalk with the $\mathrm{A}_{2} \mathrm{~B}$ receptors is possible, as $A_{2} B$ AdoR via its coupling to $G_{\alpha q}$ can feed into the PLC mediated pathway and support $A_{1}$ and $A_{3}$ AdoR signaling (53, 54).

Many reports show expression of all four subtypes of AdoR by DCs in varying degrees $(55,56)$. However, the levels of expression and their distribution among defined subset of DC remain uncertain. When analysing the available data on AdoR expression by DCs at a glance it becomes clear that AdoR expression correlates with the maturation status of DC. Human immature DC express $A_{1}$ and $A_{3}$ AdoR, which after engagement activate and recruit DCs to inflammatory sites (57). Upon maturation $\mathrm{A}_{2}$ AdoR emerge in DCs, now triggering rather inhibitory effects such as reduced secretion of IL-6, IL-12, and IFN $\gamma$ (58). Here, differential expression of AdoR by DCs serves the purpose of regulating inflammatory processes. I.e., in the beginning of an insult, immature DCs are rendered active and are recruited to the inflammatory site whereas later $\mathrm{A}_{2}$-type AdoR expression limits over boarding inflammatory reactions. However, with several ways of cross talk between AdoR (as described above), differential expression by different cell types as well as varying affinities for purines, it is nearly impossible to assign one defined effect on cell physiology to the sole action of one AdoR or to one ligand in vivo. But in vitro studies can at least give insight into general pathways modulated by Ado.

\section{Effects of Ado on Functions of DCs}

Despite the fact that four different AdoR can activate different pathways at the same time that may have opposite effects on immune cell activation, many reports unequivocally demonstrate immune suppressive actions of Ado on DCs. In particular cAMP elevating AdoR $\mathrm{A}_{2} \mathrm{~A}$ and $\mathrm{A}_{2} \mathrm{~B}$ mediate rather inhibitory functions in DCs (53). For instance, after stimulation of respective AdoR in vitro, human DCs downmodulate secretion of IL-12 and TNF $\alpha$. The cells expressed low amounts of MHC class II and were functionally impaired in stimulating proliferation of allogenic $\mathrm{T}$ cells. Further parameters of DC activation such as CXCL10, CCL2 and CCL12 secretion were also downregulated by Ado $(56,59-62)$. All of these features are indicators for a less mature phenotype of DC, which can be regarded as a tolerogenic type of DC (63).

In an even broader context a $\mathrm{CD}^{+}{ }^{+}$cellular environment may be important to keep DC in "steady state" condition. In vivo genetic ablation of CD73 in mice leads to enhanced inflammatory reactions in a contact hypersensitivity model that is driven by increased migration of skin DCs to peripheral lymph nodes (64). Moreover, when analyzing the expression of $\mathrm{T}$ cell costimulatory molecules by different DC subsets after application of the hapten TNCB, we found increased expression of CD86 in subsets of skin DCs in CD73 deficient as compared to control mice. These data are further corroborated by findings using stimulation or blockade of Ado deaminase (ADA), an enzyme that is crucial for degradation of extracellular Ado. ADA is expressed by DCs during ongoing inflammation to degrade CD73 derived Ado and to maintain their hyper-reactive state (65). In contrast, in absence of ADA Ado levels in cellular environments are increased, as a consequence tolerogenic functions of DCs are enhanced (60). Moreover, addition of ADA to DC:T cell cultures, which leads to depletion of Ado from the cellular environment, enhanced priming of effector T cells and suppressed induction of Treg (66). In aggregate, adequate levels of extracellular Ado in peripheral tissues may be of importance to prevent overshooting DC activity 


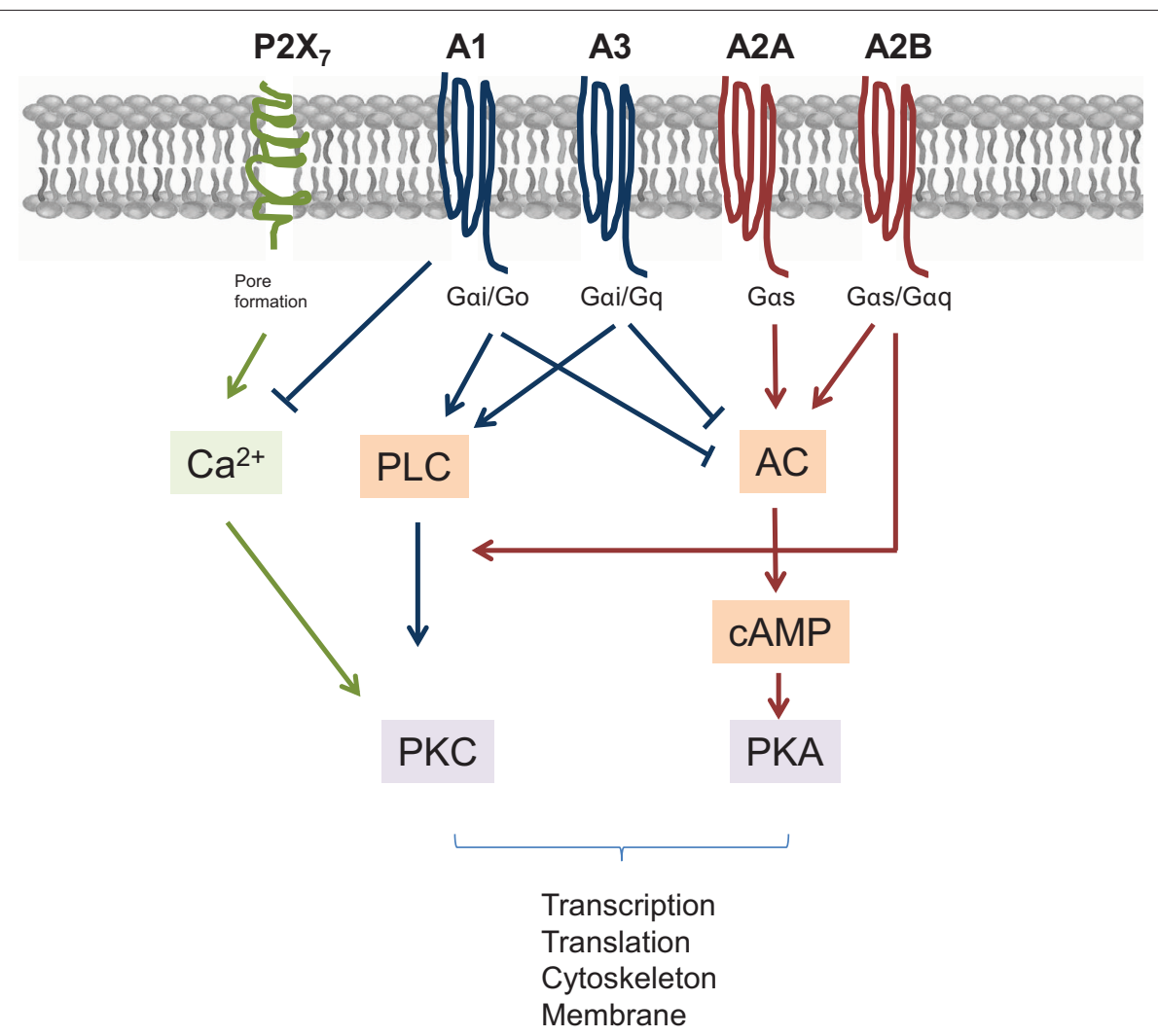

FIGURE 2 | Scheme of major pathways and interconnections of AdoR and P2X 7 ATP receptors. All receptors signal through G proteins. Different types of G proteins determine the further outcome. Briefly, A2A and A2B AdoR elevate adenylyl cyclase (AC) leading to activation of protein kinase A (PKA) through elevated cAMP levels. $A C$ and thus CAMP is suppressed by $A 1$ and $A 3$ AdoR engagement, which themselves signal via phospholipase $C$ (PLC) and proteinkinase $C$ (PKC). However, raising $\mathrm{Ca}^{2+}$ levels, which transmit a P2X 7 derived signal are blocked by A1 AdoR. Finally, A2B AdoR can augment signals derived from A1 and A3 as it stimulates Ca ${ }^{2+}$ mediated PKC activation also.

and to maintain their "steady state," which has been shown to be crucial for the tolerogenic function of DCs (67).

But beyond the mere prevention of DC maturation by Ado, the DC phenotype may be impacted in more fundamental ways. For example engagement of $\mathrm{A}_{2}$ AdoR in DCs enables them to actively suppress immune reactions. The mechanisms include the stimulation of IL-10 secretion or the upregulation of $\mathrm{T}$ cell inhibitory molecules such as $\mathrm{B} 7 \mathrm{H} 1$, resulting in tolerant $\mathrm{T}$ cells as their proper activation by DCs is impaired $(62,68,69)$.

Even "imprinting" tolerogenic functions in DCs has been attributed to AdoR engagement. Li et al. (70) were able to attenuate acute kidney injury by infusing DCs pretreated ex vivo with $\mathrm{A}_{2} \mathrm{~A}$ AdoR agonists. This phenotype of Ado tolerogenic DCs was stable for more than a week and its action in vivo relies on impeding NKT cell activation by a so far unknown mechanism. AdoR expression can also be intrinsically upregulated by already immunosuppressive DC subtypes to bolster their immunoregulatory functions. For instance, in a tolerogenic pediatric DC subtype, IL-10 is upregulated after Fc receptor mediated stimulation along with increased expression of the $\mathrm{A}_{2} \mathrm{~A}$ AdoR, which after Engagement further augments their IL-10 production (71). Thus, $\mathrm{A}_{2} \mathrm{~A}$ AdoR expression helps to reinforce the immunosuppressive capacity of the DCs.

\section{SIGNALING OF AdoR IN DCs}

\section{The Molecular Mechanisms of cAMP in DCs}

The main intracellular suppressive pathways triggered by $A_{2}$ AdoR types involve cAMP as a second messenger. Roughly, both $\mathrm{A}_{2}$-type AdoR elevate cAMP levels by activating Adenylyl Cylase (AC). Further downstream cAMP signals via PKA that regulates gene transcription via NF- $\kappa \mathrm{B}, \mathrm{HIF}-1 \alpha$ and CREB. In addition, $\mathrm{A}_{2} \mathrm{~B}$ AdoR also acts on PLC, inducing raising intracellular $\mathrm{Ca}^{2+}$ levels.

In a recent transcriptomic approach performed in bone marrow derived DCs (72), elevated activity of AC was connected to both, inhibition of AKT signaling and to activation of PKA (Figure 3). PKA has relevance for host defense capacities, as inhibition of Salt induced kinases (SIK) by cAMP-activated and PKA-mediated phosphorylation was shown to suppress secretion of the pro-inflammatory cytokines IL-6, IL-12, and TNF $\alpha$ by DCs and macrophages (73-75). Moreover, one of the SIK targets is the CREB-regulated transcription coactivator 3 (CRTC3) that can be phosphorylated at several serine residues. Phosphorylation of CRTC3 is inhibited by the cAMP-activated PKA, leading to translocation of the 


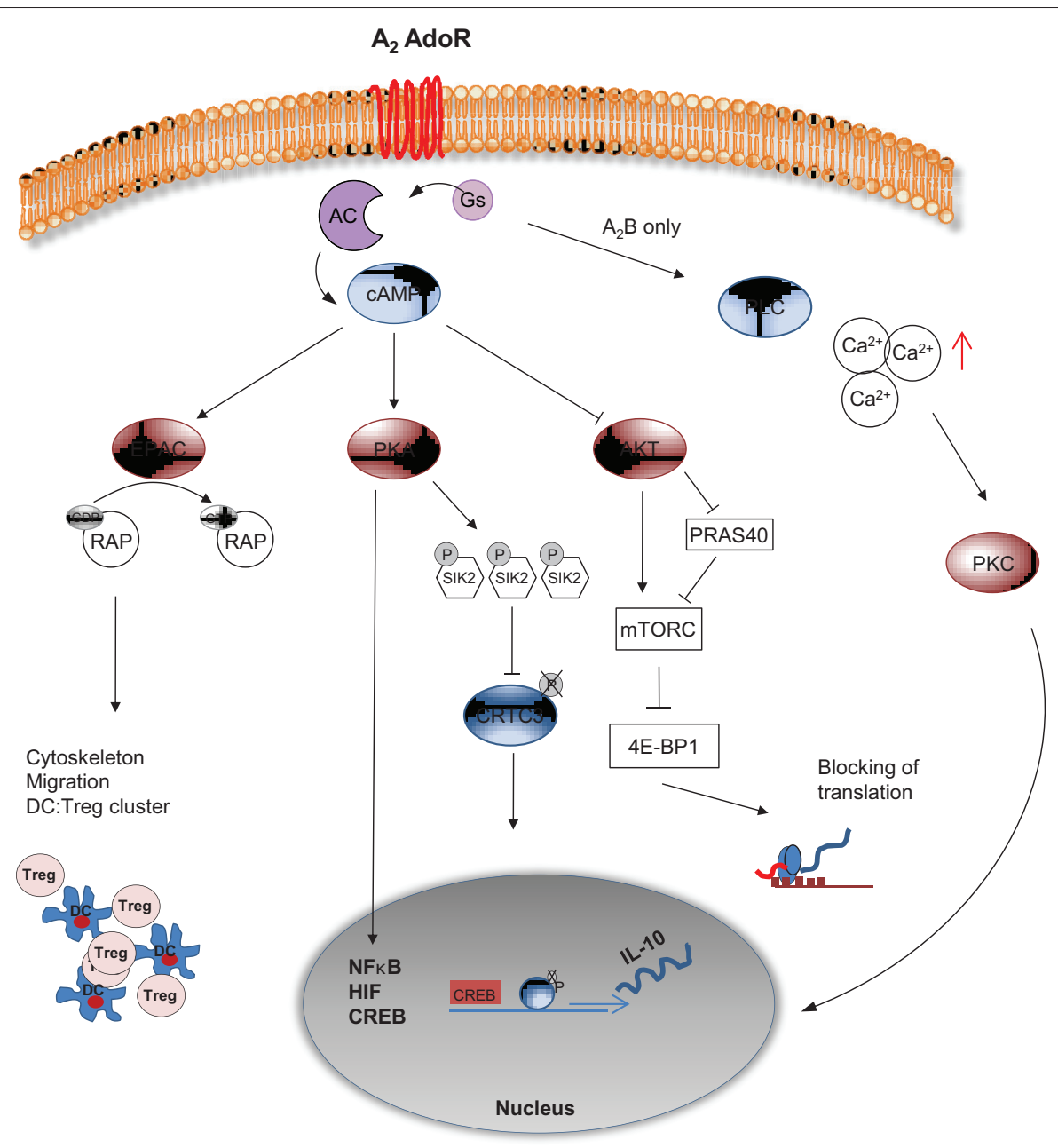

FIGURE 3 | cAMP mediated intracellular signaling of A2 AdoR. A2A and A2B AdoR activate adenylyl cyclase and elevate cAMP levels. The A2B AdoR can concomitantly activate Phospholipase C (PLC), thereby triggering elevated levels of free Calcium $\left(\mathrm{Ca}^{2+}\right)$. PKC mediated activation of NF- $\mathrm{KB}$ related gene expression follows. CAMP can suppress AKT activation leading to reduced mTORC activity either directly or via PRAS40. Without proper mTORC activity 4E-BP1 complex will terminate translation of proteins widely necessary for activation of cells. Additionally cAMP can signal via PKA, leading to hyper phosphorylation of Salt induced kinase (SIK) 2, allowing the phosphorylated transcription factor CRTC3 to cluster with CREB and to initiate translation of IL-10. Besides, further interaction of PKA with transcription factors such as NF-kB, HIF and CREB can induce "inhibitory" gene expression. A PKA independent pathway is mediated by EPAC, an enzyme that activates RAP via GTP binding, leading to profound changes in cytoskeleton and migration of DCs. As a result inhibitory DC:Treg clusters are formed and the immunological synapse may be changed in a tolerogenic fashion.

non-phosphorylated CRTC3 into the nucleus, where interaction with activated CREB upregulate IL-10 gene transcription (74).

In parallel to PKA activation, AKT activity is downregulated by elevated cAMP levels, promoting mTOR inhibition via PRAS40 (76). As a result, the downstream effectors of mTOR involved in the synthesis of cellular proteins, such as $4 \mathrm{E}-\mathrm{BP} 1$ are hypophosphorylated. In this state, $4 \mathrm{E}-\mathrm{BP} 1$ forms complexes with eukaryotic translation initiation factors and prevents translation (77). mTOR signaling regulation by AdoR driven cAMP content in DC may act as an important regulator of the antibacterial inflammatory response in monocytes, macrophages and primary dendritic cells $(78,79)$.

\section{Effects of AdoR Triggered cAMP Levels on Phenotype and Function}

Despite that AdoR triggered cAMP elevation has multiple molecular targets the overall effect is obvious, as several reports show clear induction of an immunocompromised and tolerogenic phenotype of DC by cAMP. This is indicated by reduced secretion of proinflammatory cytokines, reduced expression of MHC class-II but elevated secretion of IL10. Also the capacity of $\mathrm{DCs}$ to prime $\mathrm{CD}^{+} \mathrm{T}$ cells in vitro was impaired in DCs with elevated intracellular levels of cAMP after induction by Ado or defined AdoR agonists such as $5^{\prime}$-N-Ethylcarboxamidoadenosine $(62,68,80-$ 83). In turn, cAMP can feed back on AdoR expression. For example, high levels of cAMP induced by agents that 
trigger Gs-protein coupled receptors, upregulates expression of $\mathrm{A}_{2}$ AdoR in PC12 tumor cells (84). This cycle may therefore vigorously enhance Ado mediated suppressive effects in cells, as cAMP triggered upregulation of AdoR provides a means that leads to an even more sustained cAMP production.

To further delineate the possible cAMP effects that are mediated by AdoR engagement, one can artificially raise the cAMP content in DCs with Cholera toxin to mimic $\mathrm{A}_{2}$ AdoR triggering. This leads yet to another subtype of tolerogenic DCs, i.e., DCs that express both isoforms of the tolerogenic molecule cytotoxic T lymphocyte antigen 2 (CTLA- $2 \alpha$ and CTLA-2 $\beta$ ) (85). These DCs resembled a semi-mature state and were able to promote TGF $\beta$-dependent Foxp3 $3^{+}$"induced" Treg conversion. Of note expression of CTLA-2 was critical for this function as genetic downregulation by siRNA reduced Treg conversion, while addition of recombinant CTLA- $2 \alpha$ increased Treg conversion in vitro. Finally, when Lee et al. (81) investigated the role of DCs in priming of Th2 cells, they showed that deletion of genes that encode the GTP binding protein $\mathrm{G} \alpha \mathrm{s}$, leads to decreased cAMP signaling in DCs and provokes Th2 T cells with a prominent allergic phenotype. In contrast, increases in cAMP levels inhibited these responses. These findings imply that $\mathrm{G}$ protein-coupled receptors in DCs, such as $\mathrm{A}_{2}$ AdoR, which are natural regulators of cAMP formation, can prevent Th2-mediated immunopathologies by rendering DCs unable to induce potent Th2 answers.

Another major pathway induced by rising cAMP levels, but independent from PKA, depends on the exchange protein EPAC. Upon cAMP mediated activation, EPAC catalyzes the GTP binding of RAP1, a major regulator of the cytoskeleton. Via this axis cAMP seems to affect cell motility, cell adhesion, chemotaxis and phagocytosis (86). For DCs in particular it has been shown that Ado released by Treg is responsible for attracting them (mediated by an EPACRAP dependent pathway), leading to formation of DC:Treg aggregates (87). In these aggregates DC undergo "tolerogenic instruction," as they start to produce IL-10, upregulate T cell inhibitory molecules and simultaneously downregulate expression of MHC class II molecules. Moreover, even the directed induction of DC:Treg clusters themselves may serve immunosuppressive functions, as Onishi et al. (88) have shown that Treg insolate effector $\mathrm{T}$ cells from proper activation by DCs by simply outcompeting them and keeping DCs in clusters.

\section{Priming of T Cells by DCs in Presence of Ado Is Altered}

Despite the many well documented and long lasting effects of AdoR engagement on function of isolated DCs, the immediate presence of Ado during initial DC:T cell contact is crucially affecting the resulting immune response. For instance, in vitro engagement of $\mathrm{A}_{2} \mathrm{~A}$ AdoR during the cognate MHC:peptide (as presented by DCs) $\mathrm{T}$ cell interaction leads to induction of $\mathrm{T}$ cell anergy and not to activation of $\mathrm{T}$ cells that normally ensues after DC:T cell interaction (89). This effect seems to be dependent on altered signaling in $\mathrm{T}$ cells, as reduced activation of the MAPK pathway was observed under these conditions. Ado:DC induced anergic $\mathrm{T}$ cells are not only refractory to restimulation, they also develop a CD25- $5^{-}$AG3 ${ }^{+}$"regulatory" phenotype that actively prevents autoimmunity. Thus, the initial tolerogenic effects of Ado during antigen presentation by DCs will further

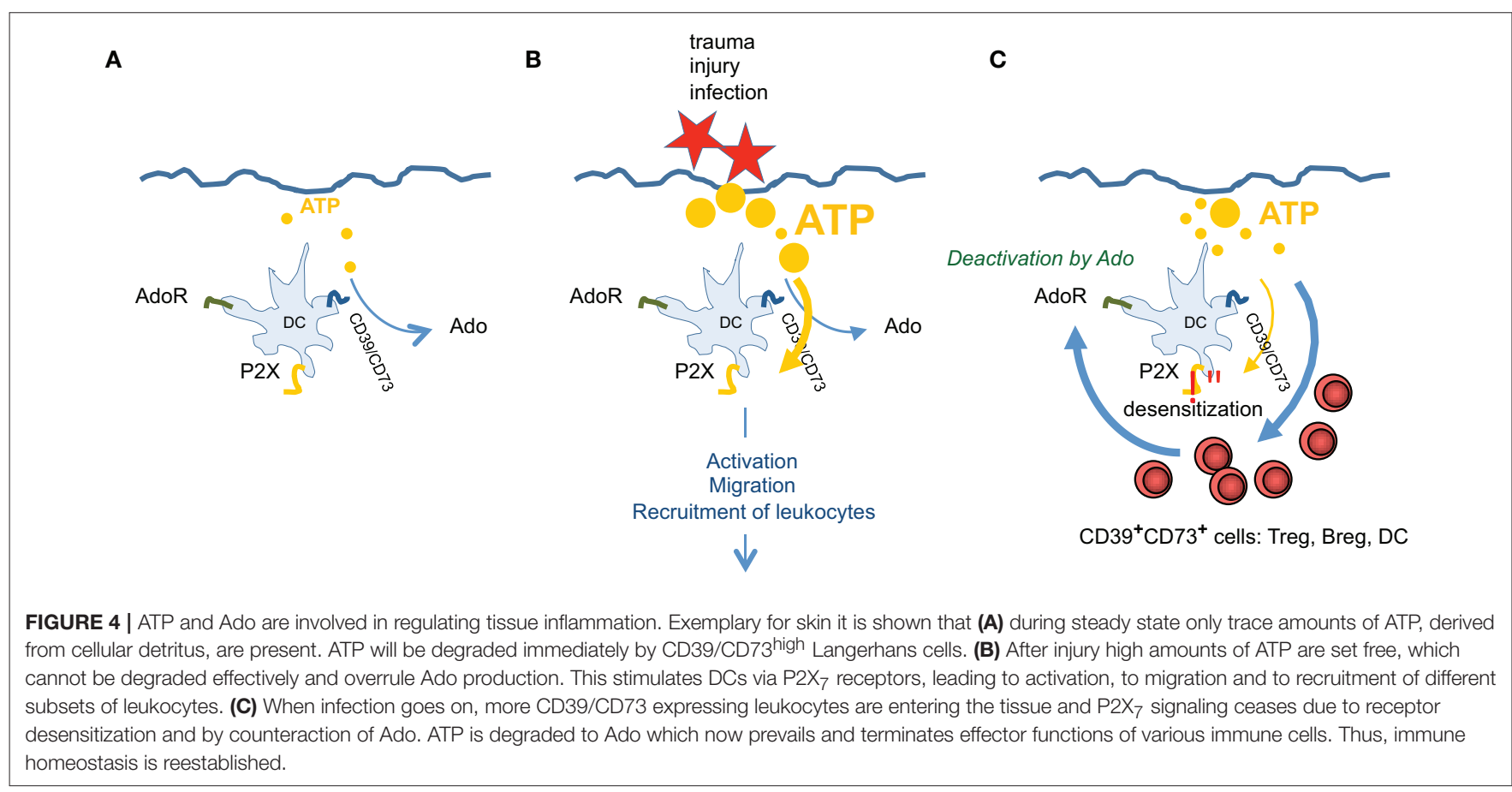


be disseminated into tissues by these induced "regulatory" $\mathrm{T}$ cells.

As DCs can express CD73 themselves, production of extracellular Ado by DCs is conceivable and regulated expression of CD73 by DC subsets may one way to tune DC function for either tolerance (high CD73) or immunity (low CD73). Indeed, in a skin model for contact hypersensitivity application of the tolerogen 2,4-dinitrothiocyanobenzene (DNTB) rendered mice tolerant toward sensitization with the hapten 2,4dinitrofluorobenzene (DNFB) (90). We found that induction of tolerance with DNTB was accompanied by increased expression of CD73 by skin migrating DCs and of note, in CD73 deficient animals tolerance induction by DNTB ceased (unpublished data). This underlines the importance of tissue derived Ado in governing DC functions under inflammatory conditions.

\section{The Complex Regulation of ATP-Ado Signaling During Inflammation}

As DCs can express all four AdoR, the ectonucleotidases

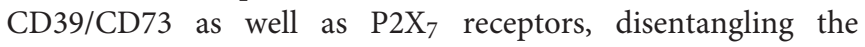
ATP and Ado effects is very complex (91). It becomes even more complicated, as the different receptors transmit either stimulatory or suppressive signals, differ in their affinity for the respective ligands and are expressed to different degrees. The well investigated example of ATP induced chemotaxis of neutrophils gives an example how important the actual physical distribution of the different receptor molecules within a cell membrane is for their function. In neutrophils the chemotactic signal induced by fMLP is translated into ATP release by panx1. It will autocrinely act back on $\mathrm{P}_{2} \mathrm{Y}_{2}$ receptors. At the same time stimulatory $A_{3}$ AdoR as well as CD39/CD73 are recruited to this part of the membrane, creating a local excitation circuit by activating PIP3, MAPK pathways and forming a "leading edge" for migration. $\mathrm{A}_{2} \mathrm{~A}$ AdoR are excluded from this membrane site and are accumulating at the "trailing edge." At the same time Ado, produced at the "leading edge" by activity of CD39/CD73, diffuses to the "back" of the cell and engages A2A receptors. This signal is transmitted by means of cAMP-PKA activation and suppresses the activation of the cell locally. As a result neutrophils are polarized and find their way along chemotactic gradients (92-94). Altogether this was an elaborative effort of several research groups and similar investigation can be done for DCs too. Here we are just at the beginning, just investigating broad effects of ATP/Ado on DC migration and DC activation, without knowing how the individual pathways are interconnected at a molecular level.

Nevertheless, in a simplified scheme one can consider ATP as rather stimulatory and proinflammatory, and $\mathrm{Ado}\left(\mathrm{A}_{2} \mathrm{~A}\right.$ and $\mathrm{A}_{2} \mathrm{~B}$ receptors elevating cAMP) as being immune suppressive. In that sense CD39/CD73 expressing DCs are key cell for modulating homeostasis and inflammation and both receptor types (for ATP and Ado) are required to actually "measure" the degree of immune suppression or activation, respectively
(Figure 4). Under non inflammatory conditions "steady state" DCs are patrolling through different tissues $(95,96)$ and sense only trace amounts of ATP, as tissues are intact and only limited amounts of extracellular ATP are produced, for instance by apoptotic cells. To maintain this homoeostatic status, high expression of CD39/CD73 ensures efficient degradation of ATP, preventing activation of the immune system. Examples are Langerhans cells in the epidermis that are highly positive for CD39 and degrade ATP effectively (37). Only when infection, tumor growth or trauma lead to elevated levels of extracellular ATP, the activating properties prevail, despite the fact that Ado receptors are expressed also. ATP simply outnumbers Ado effects. Subsets of immature peripheral DCs are recruited by $\operatorname{ATP}(58,97)$ and an immune response is initiated. But counter regulatory mechanisms are initiated at the same time. For instance $\mathrm{P}_{2} \mathrm{X}_{7}$ receptors become refractory to repeated stimulation by high ATP concentrations (37), making the DCs insensible to ATP mediated activation (58). Moreover, recruitment of regulatory $\mathrm{T}$ cells to inflammatory sites, which express high levels of CD39 and CD73, accelerates the degradation of ATP to Ado $(98,99)$. So the balance tips toward an Ado enriched ambiance that progressively exerts anti-inflammatory functions. More Ado means reduced proinflammatory functions of DCs $(69,70,81,100,101)$, less migration of DCs from tissue to lymph nodes (64) and increased induction of regulatory $\mathrm{T}$ cells $(60,63,87,89)$. Thus, slowly immune homeostasis is reestablished.

\section{CONCLUSION}

The turnover of extracellular ATP to Ado by cell bound CD39 and CD73 offers a possibility to shape the tissue environment from an inflammatory (ATP high) to an immune suppressive habitat. DCs participate in this process as they (i) express ATP degrading enzymes CD39 and CD73 and (ii) harbor AdoR. Therefore, immunosuppressive effects of Ado can be mediated in two ways by DCs: First, DC derived Ado suppresses activation of $\mathrm{T}$ cells and fosters the induction of anergic and/or regulatory $\mathrm{T}$ cells during the cognate DC:T cell interactions. Secondly, Ado derived from adjacent cells act on DCs, preventing DC maturation and development of effector functions. These steady state DCs are considered tolerogenic. Thus, an Ado enriched tissue environment may be of importance to maintain the "steady state" of DCs to prevent autoimmunity.

\section{AUTHOR CONTRIBUTIONS}

CS-V and SR contributed equally. SR prepared figures and CS-V performed experiments. All authors wrote the paper.

\section{FUNDING}

This work was supported by the DFG by a grant to the TR156, B03. 


\section{REFERENCES}

1. Seminario-Vidal L, Okada SF, Sesma JI, Kreda SM, Van Heusden CA, Zhu Y, et al. Rho signaling regulates pannexin 1-mediated ATP release from airway epithelia. J Biol Chem. (2011) 286:26277-86. doi: 10.1074/jbc.M111.260562

2. Onami K, Kimura Y, Ito Y, Yamauchi T, Yamasaki K, Aiba S. Nonmetal haptens induce ATP release from keratinocytes through opening of pannexin hemichannels by reactive oxygen species. J Invest Dermatol. (2014) 134:195160. doi: 10.1038/jid.2014.93

3. Dosch M, Gerber J, Jebbawi F, Beldi G. Mechanisms of ATP release by inflammatory cells. Int J Mol Sci. (2018) 19:E1222. doi: 10.3390/ijms19041222

4. Pastor-Anglada M, Perez-Torras S. Who is who in adenosine transport. Front Pharmacol. (2018) 9:627. doi: 10.3389/fphar.2018.00627

5. Browne LE, Compan V, Bragg L, North RA. P2X7 receptor channels allow direct permeation of nanometer-sized dyes. J Neurosci. (2013) 33:3557-66. doi: 10.1523/JNEUROSCI.2235-12.2013

6. Schenk U, Westendorf AM, Radaelli E, Casati A, Ferro M, Fumagalli M, et al. Purinergic control of T cell activation by ATP released through pannexin-1 hemichannels. Sci Signal (2008) 1:ra6. doi: 10.1126/scisignal.1160583

7. Yip L, Woehrle T, Corriden R, Hirsh M, Chen Y, Inoue Y, et al. Autocrine regulation of T-cell activation by ATP release and P2X7 receptors. FASEB J. (2009) 23:1685-93. doi: 10.1096/fj.08-126458

8. Woehrle T, Yip L, Elkhal A, Sumi Y, Chen Y, Yao Y, et al. Pannexin-1 hemichannel-mediated ATP release together with P2X1 and P2X4 receptors regulate T-cell activation at the immune synapse. Blood (2010) 116:3475-84. doi: 10.1182/blood-2010-04-277707

9. Yoshida H, Kobayashi D, Ohkubo S, Nakahata N. ATP stimulates interleukin-6 production via $\mathrm{P} 2 \mathrm{Y}$ receptors in human $\mathrm{HaCaT}$ keratinocytes. Eur J Pharmacol. (2006) 540:1-9. doi: 10.1016/j.ejphar.2006.04.008

10. Inoue K, Hosoi J, Denda M. Extracellular ATP has stimulatory effects on the expression and release of IL-6 via purinergic receptors in normal human epidermal keratinocytes. J Invest Dermatol. (2007) 127:362-71. doi: $10.1038 /$ sj.jid. 5700526

11. Cheng SE, Lee IT, Lin CC, Wu WL, Hsiao LD, Yang CM. ATP mediates NADPH oxidase/ROS generation and COX-2/PGE2 expression in A549 cells: role of P2 receptor-dependent STAT3 activation. PLoS ONE (2013) 8:e54125. doi: 10.1371/journal.pone.0054125

12. Kataoka A, Tozaki-Saitoh H, Koga Y, Tsuda M, Inoue K. Activation of P2X7 receptors induces CCL3 production in microglial cells through transcription factor NFAT. J Neurochem. (2009) 108:115-25. doi: 10.1111/j.1471-4159.2008.05744.x

13. Shieh CH, Heinrich A, Serchov T, Van Calker D, Biber K. P2X7-dependent, but differentially regulated release of IL-6, CCL2, and TNF-alpha in cultured mouse microglia. Glia (2014) 62:592-607. doi: 10.1002/glia.22628

14. Gu BJ, Wiley JS. Rapid ATP-induced release of matrix metalloproteinase 9 is mediated by the P2X7 receptor. Blood (2006) 107:4946-53. doi: 10.1182/blood-2005-07-2994

15. Zimmermann H. Extracellular ATP and other nucleotides-ubiquitous triggers of intercellular messenger release. Purinergic Signal (2016) 12:25-57. doi: 10.1007/s11302-015-9483-2

16. Weber FC, Esser PR, Muller T, Ganesan J, Pellegatti P, Simon MM, et al. Lack of the purinergic receptor P2X(7) results in resistance to contact hypersensitivity. J Exp Med. (2010) 207:2609-19. doi: 10.1084/jem.20092489

17. Henri S, Guilliams M, Poulin LF, Tamoutounour S, Ardouin L, Dalod M, et al. Disentangling the complexity of the skin dendritic cell network. Immunol Cell Biol. (2010) 88:366-75. doi: 10.1038/icb.2010.34

18. Sharpe GR, Gillespie JI, Greenwell JR. An increase in intracellular free calcium is an early event during differentiation of cultured human keratinocytes. FEBS Lett. (1989) 254:25-8. doi: 10.1016/0014-5793(89)81002-6

19. Suter MM, Crameri FM, Slattery JP, Millard PJ, Gonzalez FA. Extracellular ATP and some of its analogs induce transient rises in cytosolic free calcium in individual canine keratinocytes. J Invest Dermatol. (1991) 97, 223-229. doi: 10.1111/1523-1747.ep12480162

20. Greig AV, Linge C, Terenghi G, Mcgrouther DA, Burnstock G. Purinergic receptors are part of a functional signaling system for proliferation and differentiation of human epidermal keratinocytes. J Invest Dermatol. (2003) 120:1007-15. doi: 10.1046/j.1523-1747.2003.12261.x
21. Di Virgilio F, Schmalzing G, Markwardt F. The Elusive P2X7 Macropore. Trends Cell Biol. (2018) 28:392-404 doi: 10.1016/j.tcb.2018.01.005

22. Amores-Iniesta J, Barbera-Cremades M, Martinez CM, Pons JA, RevillaNuin B, Martinez-Alarcon L, et al. Extracellular ATP activates the NLRP3 inflammasome and is an early danger signal of skin allograft rejection. Cell Rep. (2017) 21:3414-26. doi: 10.1016/j.celrep.2017.11.079

23. Macleod AS, Rudolph R, Corriden R, Ye I, Garijo O, Havran WL Skin-resident $\mathrm{T}$ cells sense ultraviolet radiation-induced injury and contribute to DNA repair. J Immunol. (2014) 192:5695-702. doi: 10.4049/jimmunol.1303297

24. Manohar M, Hirsh MI, Chen Y, Woehrle T, Karande AA, Junger WG. ATP release and autocrine signaling through $\mathrm{P} 2 \mathrm{X} 4$ receptors regulate gammadelta T cell activation. J Leukoc Biol. (2012) 92:787-94. doi: 10.1189/jlb.0312121

25. Tran JN, Pupovac A, Taylor RM, Wiley JS, Byrne SN, Sluyter R. Murine epidermal Langerhans cells and keratinocytes express functional P2X7 receptors. Exp Dermatol. (2010) 19:e151-7. doi: 10.1111/j.1600-0625.2009.01029.x

26. Pastore S, Mascia F, Gulinelli S, Forchap S, Dattilo C, Adinolfi $\mathrm{E}$, et al. Stimulation of purinergic receptors modulates chemokine expression in human keratinocytes. J Invest Dermatol. (2007) 127:660-7. doi: $10.1038 /$ sj.jid.5700591

27. Ishimaru M, Tsukimoto M, Harada H, Kojima S. Involvement of P2Y(1)(1) receptor in IFN-gamma-induced IL-6 production in human keratinocytes. Eur J Pharmacol. (2013) 703:67-73. doi: 10.1016/j.ejphar.2013.02.020

28. Mahrle G, Orfanos CE. Decreased membrane-bound ATP-hydrolytic activity in psoriatic epidermis. Br J Dermatol. (1974) 91:529-40. doi: 10.1111/j.1365-2133.1974.tb12941.x

29. Killeen ME, Ferris L, Kupetsky EA, Falo L Jr, Mathers AR. Signaling through purinergic receptors for ATP induces human cutaneous innate and adaptive Th17 responses: implications in the pathogenesis of psoriasis. J Immunol. (2013) 190:4324-36. doi: 10.4049/jimmunol.1202045

30. Diaz-Perez JA, Killeen ME, Yang Y, Carey CD, Falo LD Jr, Mathers AR. Extracellular ATP and IL-23 form a local inflammatory circuit leading to the development of a neutrophil-dependent psoriasiform dermatitis. J Invest Dermatol. (2018). doi: 10.1016/j.jid.2018.05.018. [Epub ahead of print].

31. Andres RM, Terencio MC, Arasa J, Paya M, Valcuende-Cavero F, Navalon P, et al. Adenosine $\mathrm{A} 2 \mathrm{~A}$ and $\mathrm{A} 2 \mathrm{~B}$ receptors differentially modulate keratinocyte proliferation: possible deregulation in psoriatic epidermis. J Invest Dermatol. (2017) 137:123-31. doi: 10.1016/j.jid.2016.07.028

32. Cohen S, Barer F, Itzhak I, Silverman MH, Fishman P. Inhibition of IL-17 and IL-23 in human keratinocytes by the A3 adenosine receptor agonist piclidenoson. J Immunol Res. (2018) 2018:2310970. doi: $10.1155 / 2018 / 2310970$

33. Jacobson KA, Merighi S, Varani K, Borea PA, Baraldi S, Aghazadeh Tabrizi M, et al. A3 adenosine receptors as modulators of inflammation: from medicinal chemistry to therapy. Med Res Rev. (2018) 38:1031-72. doi: $10.1002 /$ med.21456

34. Gessi S, Merighi S, Borea PA. Targeting adenosine receptors to prevent inflammatory skin diseases. Exp Dermatol. (2014) 23:553-4. doi: 10.1111/exd.12474

35. Merighi S, Borea PA, Varani K, Gessi S. Deregulation of adenosine receptors in psoriatic epidermis: an option for therapeutic treatment. J Invest Dermatol. (2017) 137:11-3. doi: 10.1016/j.jid.2016.08.001

36. Mizumoto N, Mummert ME, Shalhevet D, Takashima A. Keratinocyte ATP release assay for testing skin-irritating potentials of structurally diverse chemicals. J Invest Dermatol. (2003) 121:1066-72 doi: 10.1046/j.1523-1747.2003.12558.x

37. Mizumoto N, Kumamoto T, Robson SC, Sevigny J, Matsue H, Enjyoji K, et al. CD39 is the dominant Langerhans cell-associated ecto-NTPDase: modulatory roles in inflammation and immune responsiveness. Nat Med. (2002) 8:358-65. doi: 10.1038/nm0402-358

38. Romio M, Reinbeck B, Bongardt S, Huls S, Burghoff S, Schrader J. Extracellular purine metabolism and signaling of CD73-derived adenosine in murine Treg and Teff cells. Am J Physiol Cell Physiol. (2011) 301:C530-9. doi: 10.1152/ajpcell.00385.2010

39. Lazarowski ER, Boucher RC, Harden TK. Constitutive release of ATP and evidence for major contribution of ecto-nucleotide pyrophosphatase and 
nucleoside diphosphokinase to extracellular nucleotide concentrations. J Biol Chem. (2000) 275:31061-8. doi: 10.1074/jbc.M003255200

40. Franco R, Valenzuela A, Lluis C, Blanco J. Enzymatic and extraenzymatic role of ecto-adenosine deaminase in lymphocytes. Immunol Rev. (1998) 161:27-42. doi: 10.1111/j.1600-065X.1998.tb01569.x

41. Hashikawa T, Hooker SW, Maj JG, Knott-Craig CJ, Takedachi M, Murakami $\mathrm{S}$, et al. Regulation of adenosine receptor engagement by ecto-adenosine deaminase. FASEB J. (2004) 18:131-3. doi: 10.1096/fj.03-0011fje

42. Moreno E, Canet J, Gracia E, Lluis C, Mallol J, Canela EI, et al. Molecular evidence of adenosine deaminase linking adenosine A2A receptor and CD26 proteins. Front Pharmacol. (2018) 9:106. doi: 10.3389/fphar.2018.00106

43. Ohta A, Ohta A, Madasu M, Kini R, Subramanian M, Goel N, et al. A2A adenosine receptor may allow expansion of $\mathrm{T}$ cells lacking effector functions in extracellular adenosine-rich microenvironments. J Immunol. (2009) 183:5487-93. doi: 10.4049/jimmunol.0901247

44. Moser GH, Schrader J, Deussen A. Turnover of adenosine in plasma of human and dog blood. Am J Physiol. (1989) 256:C799-806. doi: 10.1152/ajpcell.1989.256.4.C799

45. Chiu GS, Freund GG. Modulation of neuroimmunity by adenosine and its receptors: metabolism to mental illness. Metabolism (2014) 63:1491-8. doi: 10.1016/j.metabol.2014.09.003

46. Eckle T, Krahn T, Grenz A, Kohler D, Mittelbronn M, Ledent $\mathrm{C}$, et al. Cardioprotection by ecto-5'-nucleotidase (CD73) and A2B adenosine receptors. Circulation (2007) 115:1581-90. doi: 10.1161/CIRCULATIONAHA.106.669697

47. Wang C, Huang CY, Lin WC. Optical ATP biosensor for extracellular ATP measurement. Biosens Bioelectron (2013) 43:355-61. doi: 10.1016/j.bios.2012.12.027

48. Tennant JP, Hourani SM. Breakdown of extracellular ATP by the prostatic and epididymal ends of the guinea pig vas deferens. Eur J Pharmacol. (2000) 387:107-9. doi: 10.1016/S0014-2999(99)00789-X

49. Vekaria RM, Unwin RJ, Shirley DG. Intraluminal ATP concentrations in rat renal tubules. $J$ Am Soc Nephrol. (2006) 17:1841-7. doi: 10.1681/ASN.2005111171

50. Frenguelli BG, Wigmore G, Llaudet E, Dale N. Temporal and mechanistic dissociation of ATP and adenosine release during ischaemia in the mammalian hippocampus. J Neurochem. (2007) 101:1400-13. doi: 10.1111/j.1471-4159.2006.04425.x

51. Sove RJ, Ghonaim N, Goldman D, Ellis CG. A computational model of a microfluidic device to measure the dynamics of oxygendependent ATP release from erythrocytes. PLoS ONE (2013) 8:e81537. doi: 10.1371/journal.pone.0081537

52. Ledderose C, Bao Y, Zhang J, Junger WG. Novel method for real-time monitoring of ATP release reveals multiple phases of autocrine purinergic signalling during immune cell activation. Acta Physiol. (2015) 213:334-45. doi: 10.1111/apha.12435

53. Borea PA, Gessi S, Merighi S, Varani K. Adenosine as a multi-signalling guardian angel in human diseases: when, where and how does it exert its protective effects? Trends Pharmacol Sci. (2016) 37:419-34. doi: 10.1016/j.tips.2016.02.006

54. Cekic C, Linden J. Purinergic regulation of the immune system. Nat Rev Immunol. (2016) 16:177-92. doi: 10.1038/nri.2016.4

55. Panther E, Idzko M, Herouy Y, Rheinen H, Gebicke-Haerter PJ, Mrowietz $\mathrm{U}$, et al. Expression and function of adenosine receptors in human dendritic cells. FASEB J. (2001) 15:1963-70. doi: 10.1096/fj.01-0169com

56. Dickenson JM, Reeder S, Rees B, Alexander S, Kendall D. Functional expression of adenosine $\mathrm{A} 2 \mathrm{~A}$ and $\mathrm{A} 3$ receptors in the mouse dendritic cell line XS-106. Eur J Pharmacol. (2003) 474:43-51. doi: 10.1016/S0014-2999(03)02041-7

57. Hasko G, Cronstein BN. Adenosine: an endogenous regulator of innate immunity. Trends Immunol. (2004) 25:33-9. doi: 10.1016/j.it.2003.11.003

58. Schnurr M, Toy T, Shin A, Hartmann G, Rothenfusser S, Soellner J, et al. Role of adenosine receptors in regulating chemotaxis and cytokine production of plasmacytoid dendritic cells. Blood (2004) 103:1391-7. doi: 10.1182/blood-2003-06-1959

59. Ben Addi A, Lefort A, Hua X, Libert F, Communi D, Ledent C, et al. Modulation of murine dendritic cell function by adenine nucleotides and adenosine: involvement of the $\mathrm{A}(2 \mathrm{~B})$ receptor. Eur J Immunol. (2008) 38:1610-20. doi: 10.1002/eji.200737781

60. Novitskiy SV, Ryzhov S, Zaynagetdinov R, Goldstein AE, Huang Y, Tikhomirov OY, et al. Adenosine receptors in regulation of dendritic cell differentiation and function. Blood (2008) 112:1822-31. doi: 10.1182/blood-2008-02-136325

61. Wilson JM, Ross WG, Agbai ON, Frazier R, Figler RA, Rieger J, et al. The A2B adenosine receptor impairs the maturation and immunogenicity of dendritic cells. J Immunol. (2009) 182:4616-23. doi: 10.4049/jimmunol.0801279

62. Challier J, Bruniquel D, Sewell AK, Laugel B. Adenosine and cAMP signalling skew human dendritic cell differentiation towards a tolerogenic phenotype with defective CD8(+) T-cell priming capacity. Immunology (2013) 138:40210. doi: 10.1111/imm.12053

63. Mahnke K, Johnson TS, Ring S, Enk AH. Tolerogenic dendritic cells and regulatory T cells: a two-way relationship. J Dermatol Sci. (2007) 46:159-67. doi: 10.1016/j.jdermsci.2007.03.002

64. Neuberger A, Ring S, Silva-Vilches C, Schrader J, Enk A, Mahnke K. Expression of CD73 slows down migration of skin dendritic cells, affecting the sensitization phase of contact hypersensitivity reactions in mice. $J$ Dermatol Sci. (2017) 87:292-9. doi: 10.1016/j.jdermsci.2017.07.002

65. Desrosiers MD, Cembrola KM, Fakir MJ, Stephens LA, Jama FM, Shameli A, et al. Adenosine deamination sustains dendritic cell activation in inflammation. J Immunol. (2007) 179:1884-92. doi: 10.4049/jimmunol.179.3.1884

66. Naval-Macabuhay I, Casanova V, Navarro G, Garcia F, Leon A, Miralles L, et al. Adenosine deaminase regulates Treg expression in autologous $\mathrm{T}$ celldendritic cell cocultures from patients infected with HIV-1. J Leukoc Biol. (2016) 99:349-59. doi: 10.1189/jlb.3A1214-580RR

67. Pletinckx K, Dohler A, Pavlovic V, Lutz MB. Role of dendritic cell maturity/costimulation for generation, homeostasis, and suppressive activity of regulatory T cells. Front Immunol. (2011) 2:39. doi: 10.3389/fimmu.2011.00039

68. Kambayashi T, Wallin RP, Ljunggren HG. cAMP-elevating agents suppress dendritic cell function. J Leukoc Biol. (2001) 70:903-10. doi: $10.1189 /$ jlb.70.6.903

69. Panther E, Corinti S, Idzko M, Herouy Y, Napp M, La Sala A, et al. Adenosine affects expression of membrane molecules, cytokine and chemokine release, and the T-cell stimulatory capacity of human dendritic cells. Blood (2003) 101:3985-90. doi: 10.1182/blood-2002-07-2113

70. Li L, Huang L, Ye H, Song SP, Bajwa A, Lee SJ, et al. Dendritic cells tolerized with adenosine A(2)AR agonist attenuate acute kidney injury. J Clin Invest. (2012) 122:3931-42. doi: 10.1172/JCI63170

71. Franco A, Kumar J, Lin G, Behnamfar N, Hsieh LE, Shimizu C, et al. Pediatric tolerogenic DCs expressing CD4 and immunoglobulin-like transcript receptor (ILT)-4 secrete IL-10 in response to FC and adenosine. Eur J Immunol. (2018) 48:482-91. doi: 10.1002/eji.201747139

72. Novak J, Fabrik I, Linhartova I, Link M, Cerny O, Stulik J, et al. Phosphoproteomics of cAMP signaling of Bordetella adenylate cyclase toxin in mouse dendritic cells. Sci Rep. (2017) 7:16298. doi: 10.1038/s41598-017-14501-x

73. Clark K, Mackenzie KF, Petkevicius K, Kristariyanto Y, Zhang J, Choi HG, et al. Phosphorylation of CRTC3 by the salt-inducible kinases controls the interconversion of classically activated and regulatory macrophages. Proc Natl Acad Sci USA. (2012) 109:16986-91. doi: 10.1073/pnas.1215450109

74. Mackenzie KF, Clark K, Naqvi S, Mcguire VA, Noehren G, Kristariyanto Y, et al. PGE(2) induces macrophage IL-10 production and a regulatory-like phenotype via a protein kinase A-SIK-CRTC3 pathway. J Immunol. (2013) 190:565-77. doi: 10.4049/jimmunol.1202462

75. Sundberg TB, Choi HG, Song JH, Russell CN, Hussain MM, Graham $\mathrm{DB}$, et al. Small-molecule screening identifies inhibition of salt-inducible kinases as a therapeutic strategy to enhance immunoregulatory functions of dendritic cells. Proc Natl Acad Sci USA. (2014) 111:12468-73. doi: 10.1073/pnas.1412308111

76. Sancak Y, Thoreen CC, Peterson TR, Lindquist RA, Kang SA, Spooner $\mathrm{E}$, et al. PRAS40 is an insulin-regulated inhibitor of the mTORC1 protein kinase. Mol Cell (2007) 25:903-15. doi: 10.1016/j.molcel.2007. 03.003 
77. Gingras AC, Gygi SP, Raught B, Polakiewicz RD, Abraham RT, Hoekstra MF, et al. Regulation of 4E-BP1 phosphorylation: a novel two-step mechanism. Genes Dev. (1999) 13:1422-37. doi: 10.1101/gad.13.11.1422

78. Schmitz F, Heit A, Dreher S, Eisenacher K, Mages J, Haas T, et al. Mammalian target of rapamycin (mTOR) orchestrates the defense program of innate immune cells. Eur J Immunol. (2008) 38:2981-92. doi: 10.1002/eji.200838761

79. Weichhart $T$, Hengstschlager $M$, Linke $M$. Regulation of innate immune cell function by mTOR. Nat Rev Immunol. (2015) 15:599-614. doi: $10.1038 /$ nri3901

80. Matsumoto T, Hasegawa H, Onishi S, Ishizaki J, Suemori K, Yasukawa M. Protein kinase $\mathrm{C}$ inhibitor generates stable human tolerogenic dendritic cells. J Immunol. (2013) 191:2247-57. doi: 10.4049/jimmunol.1203053

81. Lee J, Kim TH, Murray F, Li X, Choi SS, Broide DH, et al. Cyclic AMP concentrations in dendritic cells induce and regulate Th2 immunity and allergic asthma. Proc Natl Acad Sci USA. (2015) 112:1529-34. doi: $10.1073 /$ pnas. 1417972112

82. Rueda CM, Jackson CM, Chougnet CA. Regulatory T-cell-mediated suppression of conventional T-cells and dendritic cells by different cAMP intracellular pathways. Front Immunol. (2016) 7:216. doi: 10.3389/fimmu.2016.00216

83. Figueiredo AB, Souza-Testasicca MC, Mineo TWP, Afonso LCC. Leishmania amazonensis-Induced cAMP triggered by adenosine $\mathrm{A} 2 \mathrm{~B}$ receptor is important to inhibit dendritic cell activation and evade immune response in infected mice. Front Immunol. (2017) 8:849. doi: 10.3389/fimmu.2017.00849

84. Pleli T, Mondorf A, Ferreiros N, Thomas D, Dvorak K, Biondi RM, et al. Activation of adenylyl cyclase causes stimulation of adenosine receptors. Cell Physiol Biochem. (2018) 45:2516-28. doi: 10.1159/000488270

85. Silva-Vilches C, Pletinckx K, Lohnert M, Pavlovic V, Ashour D, John V, et al. Low doses of cholera toxin and its mediator cAMP induce CTLA-2 secretion by dendritic cells to enhance regulatory T cell conversion. PLoS ONE (2017) 12:e0178114. doi: 10.1371/journal.pone.0178114

86. Garay J, D'angelo JA, Park Y, Summa CM, Aiken ML, Morales E, et al. Crosstalk between PKA and Epac regulates the phenotypic maturation and function of human dendritic cells. J Immunol. (2010) 185:3227-38. doi: 10.4049/jimmunol.0903066

87. Ring S, Pushkarevskaya A, Schild H, Probst HC, Jendrossek V, Wirsdorfer $\mathrm{F}$, et al. Regulatory $\mathrm{T}$ cell-derived adenosine induces dendritic cell migration through the Epac-Rap1 pathway. J Immunol. (2015) 194:3735-44. doi: 10.4049/jimmunol.1401434

88. Onishi Y, Fehervari Z, Yamaguchi T, Sakaguchi S. Foxp3+ natural regulatory $\mathrm{T}$ cells preferentially form aggregates on dendritic cells in vitro and actively inhibit their maturation. Proc Natl Acad Sci USA. (2008) 105:10113-8. doi: 10.1073/pnas.0711106105

89. Zarek PE, Huang CT, Lutz ER, Kowalski J, Horton MR, Linden J, et al. A2A receptor signaling promotes peripheral tolerance by inducing T-cell anergy and the generation of adaptive regulatory T cells. Blood (2008) 111:251-9. doi: 10.1182/blood-2007-03-081646

90. Iijima M, Katz SI. Specific immunologic tolerance to dinitrofluorobenzene following topical application of dinitrothiocyanobenzene: modulation by suppressor $\mathrm{T}$ cells. J Invest Dermatol. (1983) 81:325-30. doi: 10.1111/1523-1747.ep12519783
91. Ferrari D, Gorini S, Callegari G, La Sala A. Shaping immune responses through the activation of dendritic cells' P2 receptors. Purinergic Signal (2007) 3:99-107. doi: 10.1007/s11302-006-9024-0

92. Schrier DJ, Imre KM. The effects of adenosine agonists on human neutrophil function. J Immunol. (1986) 137:3284-9.

93. Thibault N, Burelout C, Harbour D, Borgeat P, Naccache PH, Bourgoin SG. Occupancy of adenosine A2a receptors promotes fMLP-induced cyclic AMP accumulation in human neutrophils: impact on phospholipase D activity and recruitment of small GTPases to membranes. J Leukoc Biol. (2002) 71:367-77. doi: 10.1189/jlb.71.2.367

94. Bao Y, Chen Y, Ledderose C, Li L, Junger WG. Pannexin 1 channels link chemoattractant receptor signaling to local excitation and global inhibition responses at the front and back of polarized neutrophils. J Biol Chem. (2013) 288:22650-7. doi: 10.1074/jbc.M113.476283

95. Mahnke K, Qian Y, Knop J, Enk AH. Induction of CD4+/CD25+ regulatory $\mathrm{T}$ cells by targeting of antigens to immature dendritic cells. Blood (2003) 101:4862-9. doi: 10.1182/blood-2002-10-3229

96. Mahnke K, Ring S, Enk AH. Antibody targeting of "Steady-State” dendritic cells induces tolerance mediated by regulatory T cells. Front Immunol. (2016) 7:63. doi: 10.3389/fimmu.2016.00063

97. Idzko M, Dichmann S, Ferrari D, Di Virgilio F, La Sala A, Girolomoni G, et al. Nucleotides induce chemotaxis and actin polymerization in immature but not mature human dendritic cells via activation of pertussis toxinsensitive P2y receptors. Blood (2002) 100:925-32. doi: 10.1182/blood.V100. 3.925

98. Deaglio S, Dwyer KM, Gao W, Friedman D, Usheva A, Erat A, et al. Adenosine generation catalyzed by CD39 and CD73 expressed on regulatory T cells mediates immune suppression. J Exp Med. (2007) 204:1257-65. doi: 10.1084/jem.20062512

99. Ring S, Oliver SJ, Cronstein BN, Enk AH, Mahnke K. CD4+CD25+ regulatory $\mathrm{T}$ cells suppress contact hypersensitivity reactions through a CD39, adenosine-dependent mechanism. J Allergy Clin Immunol. (2009)123:e1282. doi: 10.1016/j.jaci.2009.03.022

100. Huang S, Apasov S, Koshiba M, Sitkovsky M. Role of A2a extracellular adenosine receptor-mediated signaling in adenosine-mediated inhibition of T-cell activation and expansion. Blood (1997) 90:1600-10.

101. Lappas CM, Rieger JM, Linden J. A2A adenosine receptor induction inhibits IFN-gamma production in murine CD4+ T cells. J Immunol. (2005) 174:1073-80. doi: 10.4049/jimmunol.174.2.1073

Conflict of Interest Statement: The authors declare that the research was conducted in the absence of any commercial or financial relationships that could be construed as a potential conflict of interest.

Copyright (c) 2018 Silva-Vilches, Ring and Mahnke. This is an open-access article distributed under the terms of the Creative Commons Attribution License (CC BY). The use, distribution or reproduction in other forums is permitted, provided the original author(s) and the copyright owner(s) are credited and that the original publication in this journal is cited, in accordance with accepted academic practice. No use, distribution or reproduction is permitted which does not comply with these terms. 